\title{
Technique for the evaluation of cold antibodies in cases for operation under hypothermia
}

\author{
EUNICE M. BATCHELOR, KATHLEEN E. BOORMAN, P. J. LINCOLN, \\ AND R. A. ZEITLIN \\ From the Blood Transfusion Centre, Sutton, Surrey
}

SYNOPSIS Cold antibodies were found in 95 out of 112 cases active at $10^{\circ} \mathrm{C}$. but in 86 of these the whole blood compatability test described in this paper was negative or very weakly positive. It is safe to transfuse blood incompatible with a cold antibody if the whole blood test is weak or negative.

All who have matched blood for patients who are to be operated upon under deep hypothermia must face the problem of cold antibodies. The direct match at room temperature and $37^{\circ} \mathrm{C}$. may well be completely negative and yet at $10^{\circ} \mathrm{C}$. there will be strong cold antibodies present giving macroscopic agglutination. Sometimes these will be iso-antibodies, notably anti- $\mathrm{P}_{1}$ or anti- $\mathrm{H}$, and often they will be auto-antibodies. If they are iso-antibodies it may be possible to choose fully compatible blood, although this becomes impracticable, when for instance, $A B R$-negative $P_{1}$-negative blood is needed in quantity. If they are auto-antibodies no selection is possible.

In this paper we have tried to answer three questions: (1) How often do cold antibodies occur at $10^{\circ} \mathrm{C}$.? (2) What is their specificity? (3) Can we devise a more helpful antibody evaluation technique? The last question is asked because it soon became obvious that the presence of cold antibodies as demonstrated by the normal saline technique at $10^{\circ} \mathrm{C}$. was not necessarily associated with a haemolytic transfusion reaction in the patient undergoing hypothermia. This is discussed more fully later.

\section{METHODS OF ANTIBODY DETECTION AND IDENTIFICATION}

PAPAIN AT $37^{\circ} \mathrm{C}$. The cells were first treated by incubating at $37^{\circ} \mathrm{C}$. 1 volume of washed packed cells with one volume of papain solution containing cysteine as activator (as used for Low's one-stage technique) for 30 minutes. One volume of serum was then incubated with 1 volume of the pre-papainized cells. As a routine sera were tested with $\mathbf{R}_{\mathbf{1}} \mathbf{R}_{\mathbf{1}}, \mathbf{R}_{\mathbf{2}} \mathbf{R}_{\mathbf{2}}$, and $\mathrm{rr}$ ( $\mathbf{R h}$-negative) $\mathbf{K}+$ cells. If an antibody was found it was identified, using a larger panel of cells fully tested for the major blood group systems, and the control, using the patient's own prepapainized cells, was also included. If the latter autoReceived for publication 7 February 1966 control were positive, the serum was absorbed with the patient's pre-papainized cells and retested against the known panel.

INDIRECT COOMBS TEST AT $37^{\circ} \mathrm{C}$. The sera were tested $\overrightarrow{\mathrm{bg}}$ the indirect Coombs test using 2 volumes of serum toळ volumes of a $3 \%$ suspension of red cells. The panel was chosen to include all major blood group antigens, wi special attention to $\mathrm{K}$ and Fya.

COLD ANTIBODY TESTS One volume of serum to be test was incubated with one volume of a $3 \%$ suspension standard cells at the lowest temperature likely to reached in hypothermia. In the majority of cases this w $10^{\circ} \mathrm{C}$. Where autoantibodies were found at $10^{\circ} \mathrm{C}$., tests were again made at $15^{\circ} \mathrm{C}$. and room temperature and it was then possible to show the additional presence of specific antibodies in cases where these had a higher temperature range than the autoantibody. Where specific antibody was detected, it was tested by the salige technique for $37^{\circ} \mathrm{C}$. activity. None was in fact found to be active at $37^{\circ} \mathrm{C}$. In a few cases showing auto-agglutination, standard cells were absorbed with the patient's own cells at $4^{\circ} \mathrm{C}$. and the tests were repeated at $10^{\circ} \mathrm{C}$., \&8 demonstrating a specific antibody. In some other cases only auto-antibody was detected which absorbed out conpletely at $4^{\circ} \mathrm{C}$. In a number of cases, however, where there was auto-agglutination at $10^{\circ} \mathrm{C}$., it was impossible for lack of serum, to test for iso-antibodies by either of the above techniques.

\section{OCCURRENCE AND SPECIFICITY OF COLD ANTIBODIES}

으

During 1964 we tested sera from 112 patients who were to be subjected to hypothermia. Using the indirect antihuman globulin technique we found onty one with antibodies active at $37^{\circ} \mathrm{C}$. As the antibo in this case was anti-K, K-negative blood was of cour\& used (there was also a cold auto-antibody preseng. At $10^{\circ} \mathrm{C}$., using a saline tube technique incubating 1 volume of serum with 1 volume of a $5 \%$ suspensiog 
of test cells, only 17 cases were found in which there was no antibody detectable. Of the remaining 95 cases $(84.8 \%)$, auto-antibodies were detected in 62 $(55 \%)$. In the main these were panagglutinins but in seven cases they were shown to be anti-I in specificity. Auto-antibodies often masked the presence of isoantibodies. We were able to demonstrate anti-H in 23 , anti- $P_{1}$ in four, anti- $A_{1}$ in one, and anti-Lewis in one (Table I). We believe that similar iso-antibodies may have been present in some of the other cases having auto-antibodies as it was not possible by the techniques employed to identify weak isoantibodies in the presence of strong auto-antibodies.

In the 33 cases $(29.5 \%)$ in which no auto-antibody was detected at $10^{\circ} \mathrm{C}$, , we found anti- $\mathrm{H}$ in 14 , anti- $P_{1}$ in four, anti-Lewis in two, anti- $A_{1}$ in three, and one case had anti-H and anti- $\mathbf{P}_{1}$. In eight cases the antibody was too weak to identify and in the one other case there was a strong unidentified cold antibody (Table I).

TABLE I

ANTIBODIES DETECTED AT $10^{\circ} \mathrm{C}$. IN 112 CASES SELECTED FOR OPERATION UNDER HYPOTHERMIA

Specificity of Antibody

No. No.

Auto

$32(28.6 \%)$

Auto plus anti-H

Auto plus anti- $\mathbf{P}_{1}$

Auto plus anti- $\mathbf{A}_{1}$

Auto plus anti-Lewis

$23(20.5 \%)$

$4(3.6 \%)$

$1 \quad(0.9 \%)$

$1 \quad(0.9 \%)$

$1 \quad(0.9 \%)$

$62(55.4 \%$

Auto plus anti-K

$14(12.5 \%)$

$4 \quad(3.6 \%)$

$1 \quad(0.9 \%)$

$1 \quad(0.9 \%)$

$2(1.8 \%)$

$24(21.5 \%)$

Anti-H plus anti-P

Anti- $\mathbf{A}_{1}$

( $(1.8 \%)$

Anti-Lewis

$\left.\begin{array}{lr}1 & (0.9 \%) \\ 8 & (7 \cdot 1 \%)\end{array}\right\}$

$9 \quad(8.0 \%)$

No antibody

$17(15 \cdot 2 \%)$

$17(15 \cdot 2 \%)$

Total

${ }^{1}$ (anti-K active at $37^{\circ} \mathrm{C}$.)

$112(100 \cdot 1 \%) \quad 112(100 \cdot 1 \%)$

In all cases in which an antibody was detected at $10^{\circ} \mathrm{C}$. our new antibody evaluation technique was employed.

\section{NEW ANTIBODY EVALUATION TECHNIQUE (WHOLE BLOOD TESTS)}

It seemed that a strong positive reaction in saline at $10^{\circ} \mathrm{C}$. might not give a true picture of the conditions prevailing either in the pump or in the patient during hypothermia. In the normal test 1 volume of a $2 \%$ suspension of red cells in saline is mixed with 1 volume of patient's serum, which is a tremendous excess of serum over red cells compared with the position in vivo. We therefore decided that an anti- body evaluation technique should be devised in which as far as possible the actual conditions existing during the operation should be copied. Mixtures should be made of donor whole blood and recipient whole blood in varying proportions and these mixtures cooled to $10^{\circ} \mathrm{C}$. for two hours (this being rather in excess of the time it was likely that the patient would be subject to hypothermia), and then examined for agglutination. The technique employed was as follows:-

THE WHOLE BLOOD TEST Whole blood for the patient is made up using equal volumes of the patient's serum and packed washed cells. Citrated blood (in the proportion of 4 parts of blood to 1 of A.C.D. as in a blood transfusion standard bottle) of the appropriate group is used as the donor whole blood.

The patient's whole blood and the donor whole blood are then run into $9 \times 50 \mathrm{~mm}$. tubes in the following proportions:
Patient's whole blood
$\begin{array}{lllll}9 & 8 & 7 & 6 & 5\end{array}$
Donor whole blood
$\begin{array}{lllll}1 & 2 & 3 & 4 & 5\end{array}$

A tube containing patient's whole blood and a tube containing donor whole blood are included in the test as controls.

The blood is left at the appropriate temperature (usually $10^{\circ} \mathrm{C}$.) for two hours. Saline is cooled to the temperature of the test and is used to dilute the whole bloods on a microscope slide before reading microscopically.

The two main differences between this technique and the normal one are first the much greater proportion of cells to serum and secondly the dilution of the patient's plasma with donor plasma.

In a few cases in which we obtained a weak positive result in whole blood tests (some just before this series) the results we obtained were compared with a sample taken from the pump during hypothermia. In all but two cases the degree of agglutination was identical with that observed in the laboratory, i.e., weak agglutination: in the two exceptional cases there was no agglutination in the pump sample in spite of weakly positive results in the whole blood test.

\section{RESULT OF WHOLE BLOOD TESTS}

AUTO-ANTIBODIES All but six cases gave completely negative results with their own cells by the whole blood technique. In the six cases there was only very weak agglutination which suggested that there could be little or no trouble due to auto-agglutination.

In cases where an iso-antibody also was present we did obtain stronger agglutination in 17 cases when tested with cells incompatible with the isoantibody, e.g., a case where the patient was group $\mathrm{A}_{1}$ and macroscopic positive reactions were obtained 
in the ordinary $10^{\circ} \mathrm{C}$. direct match against all cells tested including the patient's own cells. Whole blood tests were negative with the patient's own cells and with $A_{1}$ cells, weak to + with $A_{2}$ cells and ++ with group 0 cells, the iso-antibody in this case being anti-H.

ISO-ANTIBODIES In 15 cases with no auto-antibodies where we detected anti-H antibodies, strong positive whole blood tests were found in eight (in one case anti- $P_{1}$ was present also and may have contributed to the degree of agglutination observed). In a further case in which the antibody was unidentified, positive reactions were obtained with all cells tested with the exception of the patient's own cells.

The results of whole blood tests are set out in Table IIa.

SELECTION OF BLOOD We selected $A_{2}$ blood for all four patients in whom the iso-antibody was anti- $\mathrm{A}_{1}$. This was as a precaution and not because of strongly positive whole blood tests. (Since this series un-

TABLE IIa

RESULTS OF WHOLE BLOOD TESTS

\begin{tabular}{l} 
Test Cells \\
\hline Own cells \\
Negative \\
Weak positive \\
Strong positive \\
Not tested \\
Cells compatible with iso-antibody \\
Negative \\
Weak positive \\
Strong positive \\
Not tested \\
Cells incompatible with iso-antibody \\
Negative \\
Weak positive \\
Strong positive \\
Not tested
\end{tabular}

selected A blood has been given when whole blo\&d tests with $A_{1}$ cells were negative to patients haviaig anti- $\mathrm{A}_{1}$ active at $10^{\circ} \mathrm{C}$. with no untoward resulti:) In three cases we selected $P_{1}$-negative blood;

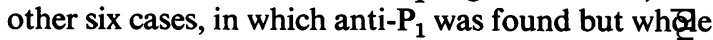
blood tests were negative, received blood unselect for $P_{1}$ type.

Anti-H, as can be seen from Table IIb, gåe weak positive reactions in 13 cases and strofig positive reactions in 22 cases. This, however, was with group 0 cells; group $A_{2}$ cells gave much weaker reactions. We selected $A_{1}$ blood for 15 cases.

In one case in which strong anti-Lewis antibod退 were detectable the patient was transfused with pooled plasma on the day before the operation $-\mathrm{r}^{\mathrm{a}}$ pre-operative sample was negative at $10^{\circ} \mathrm{C}$. with both $\mathrm{Le}^{\mathrm{a}}$ and $\mathrm{Le}^{\mathrm{b}}$ positive cells, showing that antibody had been neutralized by the transfused Lewis substances in the plasma.

In the one case in which there was a strontg unidentified cold antibody which gave positive results on whole blood tests at $10^{\circ} \mathrm{C}$. the patient was only cooled to $20^{\circ} \mathrm{C}$., at which temperature the antiboryy was not detectable.

Table III contrasts the results of the normal and whole blood compatibility tests on the blood given in 95 cases.

\section{TABLE III}

COMPATIBILITY OF BLOOD USED AT $10^{\circ} \mathrm{C}$. Reaction in vitro By Normal Technique By Whole Blood Techniqu

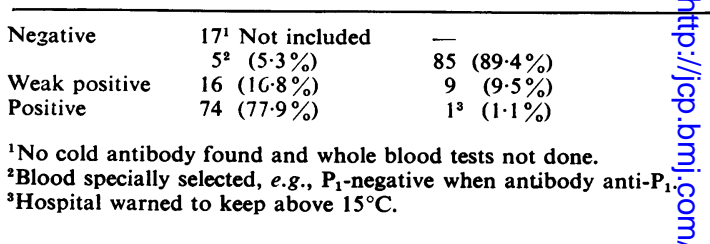

TABLE IIb

RESULTS OF WHOLE BLOOD TESTS

Specificity of Antibody

\begin{tabular}{llll} 
Reactions with Own Cells & $\begin{array}{l}\text { Reactions with Cells Compatible } \\
\text { with Iso-antibcdy }\end{array}$ \\
\hline Negative $\begin{array}{l}\text { Weak Positive } \\
\text { Positive }\end{array}$ & $\begin{array}{l}\text { Not } \\
\text { Tested }\end{array}$ & $\begin{array}{l}\text { Negative Weak Positive Not } \\
\text { Positive }\end{array}$ \\
Tested
\end{tabular}
Reactions with Cells Incompatible
with Iso-antibody

Negative Weak Positive Not Weak
Positive Tested

\section{Auto}

Auto plus anti-H

Auto plus antiP $\mathbf{P}_{1}$

Auto plus anti-A

Auto plus anti-Lewis

Auto-plus anti-K

Anti-H

Anti-P,

Anti-H plus anti-P

Anti-A

Anti-A plus weak antibody

Anti-Lewis

Unidentified strong

Unidentified weak

Totals

$\begin{array}{rr}29 & 3 \\ 21 & 2 \\ 3 & 1 \\ 1 & - \\ 1 & - \\ 1 & \\ 14 & \\ 4 & \\ 1 & \\ 1 & \\ 1 & \\ 1 & \\ 8 & \\ 86 & 6\end{array}$

$\begin{array}{ll}0 & \\ 0 & \\ 0 & 0 \\ - & - \\ & - \\ & \\ & 1 \\ & 1 \\ & \end{array}$

$\begin{array}{rrr}16 & 7 & 0 \\ 3 & 1 & 0 \\ 1 & - & - \\ 1 & - & - \\ 1 & & \\ 12 & 2 & \\ 4 & & \\ 1 & & \\ 1 & 2 & \\ 8 & & \\ 48 & 12 & \end{array}$

$\begin{array}{rrr}7 & 15 \\ 1 & 1 \\ 1 & & 1 \\ 6 & 7 \\ & 1 \\ 2 & \\ & \\ 17 & 26\end{array}$


DISCUSSION

In no case in this series have the clinicians in charge of the case reported a clinical reaction and questioned the possibility of any blood group incompatibility. It is possible that it would be equally safe to transfuse blood which gave $(+)$ or greater degree of agglutination in the whole blood tests. On the other hand this is a simple method by which blood can be selected so that the risk of agglutination occurring during hypothermia is reduced to a minimum. The resulting selection of blood is not unduly onerous. As stated above, we actually selected $A_{1}$ blood for 15 cases, $P_{1}$-negative blood for three cases, and $A_{2}$ blood for four cases. By our present criteria we could have reduced the numbers requiring selected blood to six needing $A_{1}$ blood, one $A_{2}$ blood, and one $P_{1^{-}}$ negative blood.

In the one case in which a strong unidentified antibody was present we were unable to select blood and the patient was not cooled below $20^{\circ} \mathrm{C}$.

\section{ADDENDUM}

During 1965 we tested a further 127 cases. The pattern of cold antibodies was essentially similar except that we identified more auto-antibodies as anti-I mainly because of the routine inclusion of cord cells in all the tests in 1965.

With regard to selection of blood, in only seven cases was blood specially selected, three cases with anti- $A_{1}$ and four with anti-H. In a further two cases in which there was strong positive agglutination with the patient's own cells by the whole blood technique at $10^{\circ} \mathrm{C}$., it was advised that the patient should not be cooled below $15^{\circ} \mathrm{C}$. in one case and $18^{\circ} \mathrm{C}$. in the other (the temperature at which auto whole blood tests were negative).

\section{Reports and Bulletins prepared by the Association of Clinical Biochemists}

The following reports and bulletins are published by the Association of Clinical Biochemists. They may be obtained from Mr. J. T. Ireland, Biochemistry Laboratory, Alder Hey Children's Hospital, Liverpool, 12. The prices include. postage, but airmail will be charged extra.

\section{SCIENTIFIC REPORTS}

1 Colorimeters with Flow Through Cells. A Critical Assessment of 4 Instruments. 1965. P. M. G. BROUGHTON and C. RILEY. 13s $6 \mathrm{~d}$.

2 Colorimeters: A critical assessment of 5 commercial instruments. 1966. P. M. G. BROUGHTON, C. RILEY, J. G. H. COOK, P. G. SANDERS and H. BRAUNSBERG. $15 \mathrm{~s}$.

\section{TECHNICAL BULLETINS}

2 A Report on the Enzyme Questionnaire Circulated by the Scientific Committee. December 1964. A. H. GOWENLOCK. $1 \mathrm{~s}$.

3 Non-recording Spectrophotometers for the Visible and Ultraviolet Ranges. A comparative table of instruments available in Great Britain. May 1965. A. H.
GOWENLOCK, P. C. NICHOLAS, and J. H. WILKINSON. 1s. $6 \mathrm{~d}$.

4 Control Solutions for Clinical Biochemistry. June 1965. P. M. G. BROUGHTON and A. H. GOWENLOCK. 1s. 6 d.

5 Recording Spectrophotometers. A comparative list of low-priced instruments readily available in Britain. July 1965 . P. SEWELL. 2s. 6d.

6 A Guide to Automatic Pipettes. A list of more than 100 instruments compiled from manufacturers' literature. August 1965. P. M. G. BROUGHTON. 5s.

7 Variability Between AutoAnalyzer Modules. August 1965. B. E. NORTHAM. 1s. 6d.

8 Flame Photometers. A comparative list of 15 instruments readily available in Britain. June 1966. C. RILEY. 4s. 